\title{
Occurrence of entomopathogenic nematodes in Golaghat District of Assam
}

\author{
Gitanjali Devi ${ }^{1}$, Jisna George ${ }^{1}$ and Mitali Saikia ${ }^{2}$
}

\author{
${ }^{1}$ Department of Nematology, Assam Agricultural University, Jorhat, Assam \\ ${ }^{2}$ Department of Life Science and Bioinformatics, Assam University, Diphu, Karbi Anglong, Assam \\ E-mail: gitanjali_devi@yahoo.in
}

\begin{abstract}
A survey of entomopathogenic nematodes was conducted in different vegetations of Golaghat district of Assam. Soil samples were tested for the presence of steinernematid and heterorhabditid nematodes by baiting with Galleria mellonella larvae. Out of 100 soil samples studied only one was positive for entomopathogenic nematodes (1\%), containing one Steinernema isolate. Morphological and morphometrical studies were undertaken to characterize the isolate. The Steinernema isolate was identified as S. kushidai.
\end{abstract}

Keywords - Entomopathogenic nematodes, Steinernema species, biocontrol agent, morphological and morphometric studies.

\section{INTRODUCTION}

Entomopathogenic nematodes (EPNs) of the genus Steinernema have been globally used as safe biocontrol agents against soil borne insect pests. Recent years have seen an increased interest in studying entomopathogenic nematodes (EPNs) not only because of their biological control potential but also to answer other research questions in the fields of ecology, biodiversity, evolution, biochemistry, symbiosis, and molecular genetics [1]. These nematodes are symbiotically associated with entomopathogenic bacteria Photorhabdus [2] and Xenorhabdus [3]. The third-stage infective juvenile (IJ) is the only free-living stage that persists in the soil in search of a host. Following entry, IJs release the symbiotic bacteria into the insect hemocoel, multiply and kill the host, usually within 24-48 h [4,5].In the previous survey, $H$. bacteriophora , S.tami, S.ceratophorum and S.abbasi have been reported from Assam [6,7]. The current survey is the first to be conducted in Golaghat district of Assam with the goal of finding EPN isolates and to identify the species present which are probably act as a biological control agents against relevant insect pests .

\section{MATERIALS AND METHODS}

Survey and sample collection: A systematic survey was undertaken in five villages, viz., Changkala senshowa, Alengmuria gaon, Dhekial gaon, Chetia gaon, Sensowa gaon of the development block Kathalguri, Golaghat district of Assam for the presence of entomopathogenic nematodes during 2016 to 2017. A total of 100 soil samples were collected randomly from diverse habitats, viz., rice field, vegetable grown area, sugarcane plantation area, banana plantation area and tea plantation area. Each soil sample was a composite of 5-20 random sub-samples taken in the same location, but at least $10 \mathrm{~m}$ away from each other and to a depth of $30 \mathrm{~cm}$, using a small shovel. Between samples, the shovel was thoroughly ringed with water and air dried to prevent contamination of the next sampling unit. Information regarding the location, standing crop in the field and soil type was recorded. Samples were packed in polythene bags. The soil was thoroughly mixed on a plastic sheet and half of each sample was used for extraction of entomopathogenic nematodes (EPNs).

Extraction of entomopathogenic nematodes (EPNs) from soil samples

EPNs were recovered from soil samples using an insect baiting technique described by Bedding and Akhurst [8]. Ten last instar Galleria mellonella (L.) larvae were placed in a $300 \mathrm{ml}$ plastic container containing moistened soil obtained from one of the samples and kept at room temperature $\left(22 \pm 2^{\circ} \mathrm{C}\right)$ for 2 weeks. The traps were checked every two days from the 5th day. Dead larvae from each container were placed in White traps to collect emerging IJ and were replaced by fresh larvae White [9].To verify the pathogenicity of collected nematodes and to establish new cultures, emerg ing nematodes were pooled for each sample and used to infect fresh G. mellonella larvae.

Morphological and morphometric characterization

Nematodes were examined live or heat-killed in Ringer's solution at $60^{\circ} \mathrm{C}$. All nematodes studied were reared in $G$. mellonella larvae. Twenty $G$. mellonella larvae were 
exposed to 1000 infective juveniles in a Petri dish lined with two moistened filter papers at room temperature $(25 \pm$ $3^{0} \mathrm{C}$ ). Mature females and males of the first and second generations were isolated by dissecting infected larvae in Ringer's solution 3 and 5 days after infection, respectively [10].First generation males and females were collected from 4-5 day post inoculated Galleria cadavers (dissected in distilled water).Infective juveniles and second generation adults were obtained during the week after their first emergence from Galleria cadavers. Nematodes were killed using hot $\left(50-60^{\circ} \mathrm{C}\right)$ Ringer's solution [11], fixed in triethanolamine formalin (TAF), processed to anhydrous glycerin by a slow evaporation method [12], mounted on glass slides and studied using an Olympus microscope. Morphological identification was done using criteria suggested by Stock and Kaya [13] and Hominick et al.,[14].The following characters were measured: total body length; maximum body diam; anal body diam.; excretory pore position; distance from anterior end to nerve ring position; distance from anterior end to base of pharynx; gubernaculum length; spicule length. In addition to the deMan formula, the other characters studied were: $\mathrm{D} \%$ (Distance from head to Excretory pore/oesophageal length $\mathrm{x}$ 100), E\% (Distance from Head to Excretory pore/tail length $x$ 100), F\% (Body width/tail length $x$ 100), SW, GS. Morphological and morphometrical data of the is olates were compared with the original description of the type species.

\section{RESULTS}

Survey data revealed that out of 100 soil samples, only one soil sample from tea plantation area of village Sensowa gaon, Golaghat district, Upper Brahmaputra valley, Assam $\left(26^{0} 56988 \mathrm{~N}\right.$ and $\left.93^{0} 99452 \mathrm{E}\right)$ was positive for entomopathogenic nematodes with $1 \%$ frequency of occurrence. The isolate was assigned to the genus Steinernema. Morphological and morphometrical studies different life stages (infective juveniles and adults of both the generations) of the isolate revealed it to closely resemble with Steinernema kushidai Mamiya,1988 [15] (Table1, Table2) in most of the characters. Body shape and anterior region of third stage infective juvenile heat killed specimen similar to other species of Steinernema. They are almost slender, gradually tapering posteriorly, some of them ensheathed in cuticle of second stage juveniles. Lip region is not set off. Mouth opening is closed. Oesophagus is long and narrow, terminating in basal bulb. Excretory pore is at level of mid oesophagus. Nerve ring is distinct, anterior to basal bulb. Cardia is distinct. Intestine is dense, and dark in appearance. Tail conical with pointed terminus. First generation male cuticle s mooth, head truncate, not set off, www.ijeab.com stoma short and wide, procorpus cylindrical, metacarpus swollen and basal bulb pyriform, nerve ring anterior to basal bulb. Testis is single reflexed. Spicules are paired, well curved, spicule head truncate or rounded. Shaft is indistinct. Blade is wide anteriorly, tapering posteriorly to a blunt tip. Spicule tip is slightly curved. Gubernaculum is tapering anteriorly to form a neck then enlarging slightly to a ventrally curved end. Tail is conical, tapering to rounded body terminus. Bursa is absent. Second generation male is similar to first generation males but smaller in size with slender body. First generation female cuticle is smooth, lateral fields is inconspicuous. Head is truncate. Stoma is short and wide. Procorpus is cylindrical. Metacorpus is swollen.Basal bulb is pyriform. Cardia is distinct. Nerve ring is just anterior to basal bulb. Gonads are amphidelphic reflexed. Vulva is a transverse slit, protruding slightly from body surface. Tail is tapering rapidly to pointed terminus, shorter than width at anus. Second generation female similar to first generation females, but smaller in size, slender body, tail straight and longer than width at anus. The morphometrics of the infective juvenile of the isolate were almost in similarity with the type specimen of Steinernema kushidai Mamiya, 1988 (Table 1, 2). The morphometrics of the first generation males of the isolate were almost in similarity with those of the original isolate (Table 1), however differed from the type isolate in some characters such as body length, body width, position of excretory pore, tail length, SW, GS. The morphometrics of the second generation males of all the isolates were almost in agreement with those of the original isolate (Table 2), however differed from the type isolate in some characters such as body length, body width, position of excretory pore and tail length. The morphometrics of the first generation females were almost similar with the type specimen. The second generation females of the isolates were differed from the type isolate in some characters such as body length, body width, position of excretory pore and position of nerve ring (Table 2). Morphometric variation was observed in adult stage of both male and female generations in some characters which were considered as intraspecific variations of $S$. kushidai. The isolates were thus identified as Steinernema kushidai which is a new record of this species from Assam, India.

\section{DISCUSSION}

The EPN was recovered at a low rate in present study; it may be due to condition of the crop land in terms of irrigation of the field, where the temperature and the soil mo isture was suitable for their persistence. One reason for the low recovery rate obtained in the present study, could be 
the fact that only one insect, G. mellonella, was used as bait insect and it may not be the appropriate host for all EPN species [10]. EPN distribution depends on temperature, precipitation and soil type and is closely related to vegetation type and presence of insect hosts [1620].Furthermore, the choice of sampling sites may contribute to differences in EPN recovery percentage [21]. Lower percentage of EPNs probably also due to chemical control of insect pests in fields which partially reduces the abundance of natural biocontrol agents. However, this low recovery percentage is not unusual, and it has already been reported from other surveys [10,22]. Rosa et al., [23] reported that most of the surveys showed their recovery rate from soil varies from $6 \%$ to $35 \%$ in Northern Ireland. Raj Kumar et al., [24] reported that out of 105 soil samples collected from Rajasthan, 5(4.76\%) were found to be positive for EPNs. Mracek and Becvar [25] and Bruck [26] reported that recovery frequency of EPNs may vary from $0.7 \%$ to $70.1 \%$. Akhurst and Brooks [27] and Griffin et al., [28] observed that entomopathogenic nematodes were more prevalent in agricultural fields than in natural habitats. The EPN positive soil sample was from sandy loam soil and this finding was in agreement with the findings of the surveys conducted by Ambika and Sivakumar [29] which revealed that the occurrence of EPNs was more in light soils like sandy loam, sandy, loamy sand, loam soils rather than in heavy soils. However EPNs are present in heavy soils like clay soil also as recorded by Shyamprasad et al., [30] and Sosamma and Rasmi [31] in the South Andamans and Kerala, respectively. In Sri Lanka, Heterorhabditis sp. was reported to be restricted to sandy soils within $100 \mathrm{~m}$ of the sea [32].

The nematode S. kushidai was isolated from the cadaver of scarabaeid beetle (Anomala cuprea) larvae in Hamakita, Shizuoka, Japan and described by Mamiya in 1988. Nguyen and Smart [11] observed variations in body length, position of excretory pore, tail length and value of $\mathrm{E} \%$ of Steinernema glaseri in relation to time of harvest. It was observed that body length of infective juvenile was $1464 \mu \mathrm{m}$ $(1256 \mu \mathrm{m}-1610 \mu \mathrm{m})$ on $3^{\text {rd }}$ day of harvest where as body length was $1306 \mu \mathrm{m}(726 \mu \mathrm{m}-1530 \mu \mathrm{m})$ on $12^{\text {th }}$ day of harvest. Shishiniova et al., [33] observed that the infective juveniles of Bulgarian strains of $S$. carpocapsae differed in some morphometric characters and indexes from the known strains from Europe, USA and South America. Bamel and Waghmare [34] recorded S. siamkayai first time from India. The isolate, S. siamkayai showed variation with respect to adult stage of both male and female generations in some characters like pharynx, excretory pore, tail length, spicule length and gubernaculum length etc. from the original description.

\section{CONCLUSION}

Although, entomopathogenic nematodes were recovered only from one soil samples out of 100 soil samples, the recovery of Steinernema kushidai highlights the importance of conducting a more intensive survey in Assam. Further studies on characterization and host ranges of these EPN species are necessary to explore and ascertain their possible utilization in biological control programme of insect pests.

\section{ACKNOWLEDGEMENT}

The authors are grateful to the Head of the Department, Department of Nematology, AAU, Jorhat, Assam and Director of Post Graduate Studies, AAU, Jorhat, Assam for providing neces sary laboratory facilities.

\section{REFERENCES}

[1].Burnell, A.M. and Stock, S.P.2000. Heterorhabditis, Steinernema and their bacterial symbionts-lethal pathogens of insects. Nematology 2(1): 31-42.

[2].Boemare, N.E., Boyer Giglio, M. H., Thaler,J.O. and Akhurst, R.J.1993.The phages and bacteriocins of Xenorhabdus spp.,Importance for the specificity of their bacterial host to the nematodes Steinernematidae and Heterorhabditidae. In: Nematodes and the Biological control of insect Pests, Bedding,RA, Akhurst RJ and Kayahk.(eds.).CSIRO Publications, Melbourne, pp.137-145.

[3].Thomas, G.M. and Poinar, Jr.,GO.1974. Xenorhabdus gen.nov. a genus of entomopathogenic ,nematophilic bacteria of the family Enterobacteriaceae. International Journal of Systematical Bacteriology 29 : 352-360.

[4].Ciche, T.A. and Ensign, J.C.2003.For the insect pathogen Photorhabdus luminescens, which end of a nematode is out? Applied and Environmental Microbiology 69: 1890-1897.

[5].Poinar, G. O., Jr. 1990. Biology and taxonomy of Steinernematidae and Heterorhabditidae. In: R. Gaugler and H. K. Kaya, (eds.). Entomopathogenic nematodes in biological control. Florida: CRC Press. Pp. 23-62

[6].Devi, G., Mishra, H., Bhattacharyya, B. and Nath, D.J. 2016. Occurrence of entomopathogenic nematode (Rhabditida: Heterorhabditidae, Steinernematidae) in white grub infested areas of Majuli, Assam, India. Journal of Biopesticides 9(2): 148-156.

[7].Devi, G.,Sarma, A.,Thakuria R.K.,Nath D.J. ,Bhuyan, P .,So mvanshi, V.S.,Sultana, R., KumarP. and Das P.

Page | 211 
2017.Isolation and identification of entomopathogenic nematodes from Assam, India. Indian Journal of Nematology 47(1):65-74.

[8].Bedding, R.A. and Akhurst, R.J. 1975. A simple technique for the detection of insect parasitic rhabditid nematodes in soil. Nematologica 21:109-110.

[9].White, G. F. 1927. A method for obtaining infective nematode larvae from cultures. Science (Washington), 6(1709): 302-303.

[10].Kary, N.E., Niknam, G., Griffin, C.T., Mohammadi, S.A. and Moghaddam, M. 2009. A survey of entomopathogenic nematodes of the families Steinernematidae and Heterorhabditidae (Nematoda: Rhabditida) in the north-west of Iran. Nematology 11(1): 107-116.

[11].Nguyen, K.B. and Smart Jr., G.C. 1995. Morphometrics of infective juveniles of Steinernema spp. and Heterorhabditis bacteriophora (Nemata: Rhabditida). Journal of Nematology 27(2): 206-212.

[12].Woodring, J.L. and Kaya, H.K. 1988.Steinernematid and heterorhabditid nematodes. In: A handbook of biology and techniques. Southern Cooperative Series Bulletin 331, Arkansas Agricultural Experiment Station, Fayetteville, AR. 30 pp.

[13].Stock, S.P., Kaya, H.K. 1996. A multivariate analysis of morphometric characters of Heterorhabditis species and the role of morphometrics in the taxonomy of the species of the genus.Journal of Parasitology 82:806813.

[14].Hominick, W.M., Briscoe, B.R., Del Pino, F.G., Jian Heng, Hunt D.J., Kozodoy, E., Mracek, Z., Nguyen, K.B., Reid, A.P., Spiridonov, S.E., Stock, P., Sturhan, D., Waturu,C., Yoshida,M. 1997. Biosystematics of entomopathogenic nematodes: current status, protocols and definitions. Journal of Helminthology 71: 271298.

[15].Mamiya, Y. 1988. Steinernema kushidai n. sp. (Nematoda: Steinernematidae) associated with scarabaeid beetle larvae from Shizuoca, Japan. Applied Entomology and Zoology 23:313-320.

[16].Nielsen, O. and Philipsen, H. 2003. Danish surveys on insects naturally infected with Entomopathogenic nematodes. Bulletin OILB/SROP 26: 131-136.

[17].Puza, V. and Mracek, Z. 2005. Seasonal dynamics of entomopathogenic nematodes of the genera Steinernema and Heterorhabditis as a response to abiotic factors and abundance of insect hosts. Journal of Invertebrate Pathology 89: 116-122.
[18].Campos Herrera, R., Escuer, M., Labrador, S., Robertson, L., Barrios, L. and Gutierrez, C. 2007. Distribution of the entomopathogenic nematodes from La Rioja (Northern Spain). Journal of Invertebrate Pathology 95: 125-139.

[19].Campos Herrera, R., Johnson, E.G., El Borai, F.E., Stuart, R.J., Graham, J.H. and Duncan, L.W. 2011. Long-term stability of entomopathogenic nematode spatial patterns in soil as measured by sentinel insects and real-time PCR assays. Annals of Applied Biology 158(1): 55-68.

[20].El Borai, F., Stuart, R.J., Campos Herrera, R., Pathak, E. and Duncan, L.W. 2012. Entomopathogenic nematodes, root weevil larvae, and dynamic interactions among soil texture, plant growth, herbivory, and predation. Journal of Invertebrate Pathology 109: 134-142.

[21].Mracek, Z., Becvar, S., Kindlann, P. and Jersakova, J. 2005. Habitat preference for Entomopathogenic nematodes, their insect hosts and new faunistic records for the Czech Republic. Biological Control 34:27-37.

[22].Hazir, S., Keskin, N., Stock, S.P., Kaya, H.K. and Ozcan, S. 2003. Diversity and distribution of entomopathogenic nematodes (Rhabditida: Steinernematidae and Heterorhabditidae) in Turkey. Biodiversity and Conservation 12(2): 375386.

[23].Rosa, J.S., Bonifassi, E., A maral, J., Lacey, L.A., Simoes, N. and Laumond, C. 2000. Natural occurrence of entomopathogenic nematodes (Rhabditida: Steinernema, Heterorhabditis) in Azores. Journal of Nematology 32: 215-222.

[24].Rajkumar, M., Parihar, A. and Siddiqui, A.U. 2001. Studies on entomopathogenic nematodes of Udaipur. In: Proceedings of National Congress of Centenary of Nematoogy in India: Appraisal and Future Plans. IARI, New Delhi, pp.118.

[25].Mracek, Z. and Becvar, S. 2000. Insect aggregations and entomopathogenic nematode occurrence. Nematology 2 (3): 297-301.

[26].Bruck, D.J. 2004. Natural occurrence of entomopathogens in Pacific Northwest nursery soil and their virulence to the black vine weevil, Otiorhynchus sulcatus (F.) (Coleoptera: Curculionidae). Environmental Entomology 33(5): 1335-1343.

[27].Akhurst, R.J. and Brooks, W.M. 1984. The distribution of entomophilic nematodes (Heterorhabditidae and Steinernematidae) in North Carolina. Journal of Invertebrate Pathology 44(2): 140-145. 
[28].Griffin, C.T., Moore, J.F. and Downes, M.J. 1991. Occurrence of insect-parasitic nematodes (Steinernematidae, Heterorhabditidae) in the Republic of Ireland. Nematologica 37(1):92-100.

[29].A mbika, S. and Sivakumar, C.V. 2002. Natural occurrence of entomopathogenic nematodes in three Northern Districts of Tamil Nadu. Indian Journal of Entomology 64(3): 288-291.

[30].Shyamprasad, G., Ranganath, H.R. and Singh, P.K. 2001. Occurrence of entomopathogenic nematodes in parts of South Andamans. Current Science 80:501502.

[31].Sosamma, V.K. and Rasmi, B. 2002. Survey of entomophilic nematodes in Kerala. Indian $J$ Nematology 32(2): 184-185.
[32].A marasinghe, L.D., Ho min ick, W.M., Brisco, B.R. and Rei, A.P. 1994. Occurrence and distribution of entomopathogenic nematodes in Sri Lanka. Journal of Helminthology 68(4): 277-286.

[33].Shishiniova, M., Budurova, L., and Gradinarov, D. 1998. Contribution to the fauna of the entomopathogenic nematodes: Rhabditida: Steinernematidae, Heterorhabditidae from Bulgaria II. Biotechnology and Biotechnological Equipment 12:104-108.

[34].Bamel, V. and Waghmare, C. 2014. Report of Ento mopathogenic Nematode, Steinernema siamkayai (Stock, Somsook and Reid 1998) (Steinernematidae: Nematoda) from fields of IARI, New Delhi. Indian Journal of Nematology 44(2): 255-258.

Table.1: Morphometrics of infective juvenile and first generation male of Steinernema sp. from fields of tea plantation, Assam in comparison with original description of Steinernema kushidai.

Measurements in $\mu \mathrm{m}$ and in the form: mean $\pm S D$ (range)

\begin{tabular}{|c|c|c|c|c|}
\hline Character & $\begin{array}{l}\text { Steinernema sp. (IJ) } \\
(\mathrm{n}=25)\end{array}$ & $\begin{array}{l}\text { Original description } \\
\text { of Steinernema } \\
\text { kushidai } \\
\text { (Infective juvenile) } \\
\text { Mamiya, } 1988 \\
(\mathrm{n}=50)\end{array}$ & $\begin{array}{l}\text { Steinernema sp. } \\
\left(1^{\text {st }} \text { gen male }\right) \\
(n=15)\end{array}$ & $\begin{array}{l}\text { Original description of } \\
\text { Steinernema kushidai } \\
\left(1^{\text {st }} \text { gen male }\right) \\
\text { Mamiya, } 1988 \\
(\mathrm{n}=20)\end{array}$ \\
\hline Body length(L) & $\begin{array}{l}619.1 \pm 61.0 \\
(505-695)\end{array}$ & $\begin{array}{l}589 \pm 39.8 \\
(524-662)\end{array}$ & $\begin{array}{l}957.3 \pm 132 \\
(805-1300)\end{array}$ & $\begin{array}{c}1400 \pm 0.16 \\
(1200-1900)\end{array}$ \\
\hline Body width(W) & $\begin{array}{c}39.5 \pm 8.1 \\
(26-50)\end{array}$ & $\begin{array}{l}26 \pm 2.5 \\
(22-31)\end{array}$ & $\begin{array}{l}62.2 \pm 96.8 \\
(50-75)\end{array}$ & $\begin{array}{l}97 \pm 19.2 \\
(75-156)\end{array}$ \\
\hline $\begin{array}{l}\text { Anterior end to excretory } \\
\text { pore }(\mathrm{EP})\end{array}$ & $\begin{array}{l}43.4 \pm 13.0 \\
(25-55)\end{array}$ & $\begin{array}{l}46 \pm 2.0 \\
(42-50)\end{array}$ & $\begin{array}{c}53.2 \pm 8.4 \\
(30-63)\end{array}$ & $\begin{array}{c}84 \pm 7.9 \\
(71-105)\end{array}$ \\
\hline $\begin{array}{l}\text { Anterior end to esophagus } \\
\text { base (ES) }\end{array}$ & $\begin{array}{l}115.0 \pm 10.0 \\
(95-135)\end{array}$ & $\begin{array}{c}111 \pm 4.1 \\
(106-120)\end{array}$ & $\begin{array}{l}138.6 \pm 8.3 \\
(120-150)\end{array}$ & $\begin{array}{c}167 \pm 7.9 \\
(156-189)\end{array}$ \\
\hline Tail length(T) & $\begin{array}{c}37.3 \pm 9.3 \\
(20-50)\end{array}$ & $\begin{array}{l}50 \pm 3.4 \\
(44-59)\end{array}$ & $\begin{array}{c}21.6 \pm 3.4 \\
(15-25)\end{array}$ & $\begin{array}{l}33 \pm 3.0 \\
(30-40)\end{array}$ \\
\hline Anal body width(ABW) & $\begin{array}{c}21.1 \pm 3.8 \\
(15-30)\end{array}$ & & $\begin{array}{c}29.6 \pm 3.5 \\
(25-35)\end{array}$ & $\begin{array}{l}42 \pm 5.0 \\
(36-54)\end{array}$ \\
\hline
\end{tabular}




\begin{tabular}{|c|c|c|c|c|}
\hline $\begin{array}{l}\text { Ratio b= } \\
(\mathrm{L} / \mathrm{ES})\end{array}$ & $\begin{array}{l}5.3 \pm 0.2 \\
(5.0-5.7)\end{array}$ & $\begin{array}{l}5.3 \pm 0.3 \\
(4.9-5.9)\end{array}$ & & \\
\hline Ratio $\mathrm{c}=(\mathrm{L} /$ Tail $)$ & $\begin{array}{c}17.8 \pm 5.9 \\
(10.1-30.2)\end{array}$ & $\begin{array}{l}11.7 \pm 0.6 \\
(9.9-12.9)\end{array}$ & & \\
\hline Spicule length(SL) & & & $\begin{array}{c}68.8 \pm 5.6 \\
(60-80)\end{array}$ & $\begin{array}{l}63 \pm 5.5 \\
(48-72)\end{array}$ \\
\hline $\begin{array}{l}\text { Gubernaculum } \\
\text { length(GL) }\end{array}$ & & & $\begin{array}{r}43.8 \pm 4.7 \\
(35-50)\end{array}$ & $\begin{array}{l}44 \pm 4.9 \\
(39-60)\end{array}$ \\
\hline $\begin{array}{l}\text { SW } \%= \\
\text { SLABW } * 100\end{array}$ & & & $\begin{array}{l}2.35 \pm 0.3 \\
(1.7-2.8)\end{array}$ & 1.50 \\
\hline $\begin{array}{l}\mathrm{D} \%= \\
(\mathrm{EP} / \mathrm{ES})^{*} 100\end{array}$ & $\begin{array}{l}0.37 \pm 0.1 \\
(0.2-0.5)\end{array}$ & $\begin{array}{c}0.41 \pm 0.01 \\
(0.38-0.44)\end{array}$ & $\begin{array}{c}0.38 \pm 0.06 \\
(0.2-0.4)\end{array}$ & $\begin{array}{c}0.51 \pm 0.04 \\
(0.42-0.59)\end{array}$ \\
\hline
\end{tabular}

Table.2: Morphometrics of second generation male; first and second generation female of Steinernema sp. from fields of tea plantation, Assam in comparison with original description of Steinernema kushidai. Measurements in $\mu m$ and in the form: mean \pm

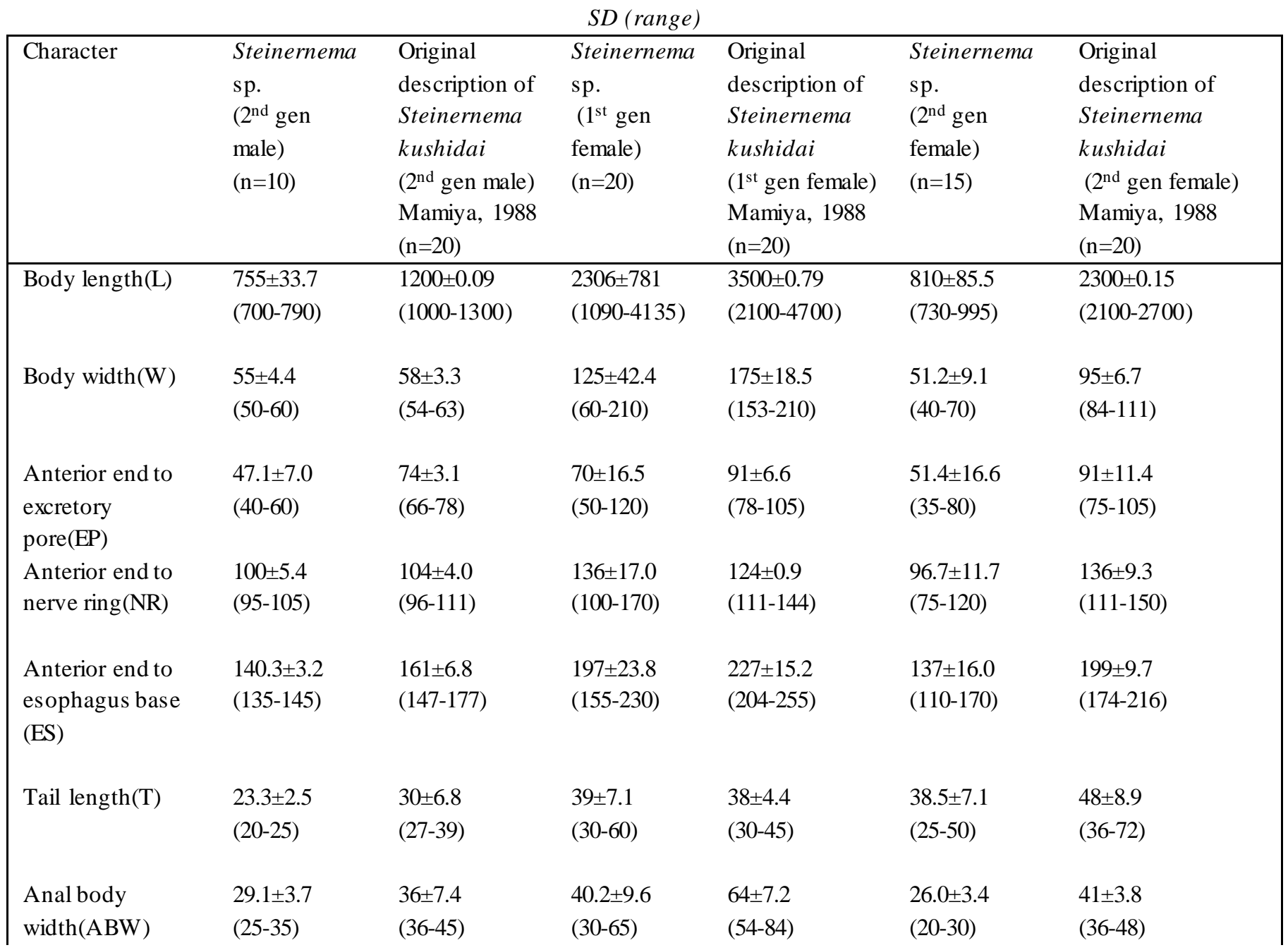




\begin{tabular}{|c|c|c|c|c|c|c|}
\hline $\begin{array}{l}\text { Spicule } \\
\text { length(SL) }\end{array}$ & $\begin{array}{l}62.5 \pm 11.2 \\
(40-70)\end{array}$ & $\begin{array}{l}58 \pm 4.0 \\
(51-63)\end{array}$ & & & & \\
\hline $\begin{array}{l}\text { Gubernaculum } \\
\text { length(GL) }\end{array}$ & $\begin{array}{l}35 \pm 9.4 \\
(20-45)\end{array}$ & $\begin{array}{l}40 \pm 3.3 \\
(30-45)\end{array}$ & & & & \\
\hline $\begin{array}{l}\mathrm{D} \%= \\
(\mathrm{EP} / \mathrm{ES}) * 100\end{array}$ & $\begin{array}{l}0.33 \pm 0.5 \\
(0.3-0.44)\end{array}$ & $\begin{array}{l}0.46 \pm 0.03 \\
(0.41-0.56)\end{array}$ & $\begin{array}{l}0.35 \pm 0.06 \\
(0.24-0.52)\end{array}$ & $\begin{array}{l}0.40 \pm 0.02 \\
(0.37-0.46)\end{array}$ & $\begin{array}{l}0.37 \pm 0.12 \\
(0.21-0.60)\end{array}$ & $\begin{array}{l}0.44 \pm 0.06 \\
(0.34-0.55)\end{array}$ \\
\hline $\begin{array}{l}\mathrm{V} \%=\text { distance } \\
\text { from anterior end } \\
\text { to vulva as } \\
\text { percentage of } \\
\text { length }\end{array}$ & & & $\begin{array}{l}55.3 \pm 4.4 \\
(44-68)\end{array}$ & $\begin{array}{l}56 \pm 1.4 \\
(54-59)\end{array}$ & $\begin{array}{l}54 \pm 4.5 \\
(45-66)\end{array}$ & $\begin{array}{l}56 \pm 2.4 \\
(50-60)\end{array}$ \\
\hline
\end{tabular}

